\title{
National Sovereignity and the Principle of Primacy in EU Law and Their Importance for the Member States
}

\author{
Verica Trstenjak ${ }^{1,2 *}$ \\ ${ }^{1}$ University of Vienna, Vienna, Austria \\ ${ }^{2}$ Max Planck Institute for International, European and Regulatory Procedural Law, Luxembourg \\ Email: verica.trstenjak@gmail.com
}

Received April 5 $5^{\text {th }}, 2013$; revised May $6^{\text {th }}, 2013$; accepted May $14^{\text {th }}, 2013$

\begin{abstract}
Copyright (C) 2013 Verica Trstenjak. This is an open access article distributed under the Creative Commons Attribution License, which permits unrestricted use, distribution, and reproduction in any medium, provided the original work is properly cited.
\end{abstract}

\begin{abstract}
The principle of primacy of the EU law has been in force for almost 50 years and belongs to the fundamental principles of EU law. It signifies that in case of a conflict between EU law and the law of the Member States, the EU law prevails. Its fundamental goal is to assure a unified and effective application of EU law in all Member States. The principle of primacy has been established by the case law of the Court of Justice of the European Union. This article discusses the principle of primacy, as developed by the Court of Justice of the European Union, and focuses on its importance for the Member States. The legal theory divides Member States into three groups with regard to what their position on the primacy of EU law in relation to the national constitution is: Member States that acknowledge full primacy, Member States that acknowledge limited primacy of EU law in relation to the national constitution, and Member States that principally assume primacy of the national constitution over EU law. Within the context of the European hierarchy, the constitutional courts of the Member States are left with the central role and power of review of constitutionality, but it remains to be seen whether in future more constitutional courts will enter a dialogue with the Court of Justice of the European Union in the form of a preliminary ruling procedure.
\end{abstract}

Keywords: Principle of Primacy; EU Legal Order; Direct Effect; National Sovereignty; Court of Justice of the European Union; Preliminary Ruling Procedure; Constitutional Law; International Law; EU Law

\section{Introduction}

The EU legal order represents one of the biggest legal orders in the world and EU law is one of the most connecting factors in Europe today. Account must be taken of the fact that the European Union currently includes 27 Member States (from July 2013 on, it will include 28 Member States as Croatia will accede to the EU) and has 500 million inhabitants. The EU legal order thus connects countries of both civil and common law system. It is in force in an area with 23 official languages, in which all acts are translated to. In order for such a legal order to function within a union that is neither a state nor a real federation, certain legal principles needed to be established. The principle of primacy is one of these principles.

The principle of primacy of EU law has been in force for almost 50 years. During this period, it has received a lot of attention not only on the level of the EU, but also from the part of Member States. For the principle of primacy of EU law interferes with one of the elements of the national sovereignty; if generally, the maxim regnum regno non praescribit leges applies, this does not hold good in relation between EU and Member States.

The present article discusses the principle of primacy, as it

"Former Advocate General at European Court of Justice, Luxembourg. was established and developed by the Court of Justice of the European Union (hereinafter referred to as: CJEU) in Luxemburg, and it focuses on the role of Constitutional Courts of the Member States, related thereto.

\section{The Main Features of the EU Legal Order}

As the CJEU stated in its famous judgment van Gend \& Loos, the EU constitutes a new legal order of international law for the benefit of which the Member States have limited their sovereign rights, albeit within limited fields, and the subjects of which comprise not only Member States but also their nation$\mathrm{als}^{1}$. The EU legal order consists of so-called "primary law", which comprises the leading principles and rules, and "secondary law", which is made up of legal acts of the institutions of the EU. Since the legislative competences of the EU institutions are specified in primary law, those competences must be exercised in conformity with it. It follows that, from this point of view, secondary Union law is subordinate to primary Union law. Primary law is laid down in the Treaty on European Union (hereinafter referred to as: TEU), the Treaty on the Functioning of the European Union (hereinafter referred to as: TFEU), the Treaty establishing a European Atomic Energy Community

${ }^{1}$ Judgment from 5 February 1963 in Case 26/62, van Gend \& Loos [1963] ECR 1. 
(hereinafter referred to as: EAEC Treaty), the protocols to those Treaties, as well as in the Charter of Fundamental Rights of the European Union. Although Article 6 (2) TEU now expressly provides for the possibility for the EU to accede to the European Convention for the Protection of Human Rights and Fundamental Freedoms, such accession has not yet taken place. The EU institutions create secondary Union law by adopting the legal acts set out in Article 288 (1) TFEU, in particular regulations and directives. The most important difference between regulations and directives is that regulations are binding in their entirety and are directly applicable in all Member States. ${ }^{2}$ By contrast, directives are binding upon the Member States to which they are addressed as to the result to be achieved within the set deadline, but they leave to the national authorities the choice of form and methods ${ }^{3}$.

One of the central actors within the EU legal system is the Court of Justice of the European Union (CJEU) in Luxemburg, whose main task is to ensure that in the interpretation and application of the EU Treaties the law is observed ${ }^{4}$. Disputes can be brought before the CJEU under different procedures. The most important procedures concern actions introduced by the European Commission for infringement of Union law by a Member State according to Article 258 TFEU as well as requests of courts or tribunals of the Member States to give preliminary rulings on the interpretation of Union law or the validity of acts adopted by the institutions according to Article 267 TFEU. In this context, the preliminary rulings procedure enables the CJEU to enter into a structured dialogue with the national courts and tribunals of the Member States, who are normally the first place for citizens to go to in order to have their rights derived from EU law taken into consideration (see von Danwitz, 2010; for a critical analysis of the impossibility for an individual seeking to enforce rights flowing from EU law to appeal to a Union court in order to enforce those rights, see Basedow, 2010a; Basedow, 2010b). Where a relevant question about the interpretation of the EU Treaties or about the validity and interpretation of secondary Union law is raised before a court or tribunal of a Member State, that court may, or, when it is a court of last resort, must request the CJEU to give a ruling thereon by way of the preliminary rulings procedure.

\section{The Relationship between EU Law and National Law}

\section{The Principle of Primacy}

\section{The Notion}

The principle of primacy of EU law (for the use of the expression supremacy, see e.g. Craig \& De Búrca, 2007; for the use of the expression primacy, see e.g. Lenaerts \& Van Nuffel, 2005; on conceptual differences between the two expressions, see Avbelj, 2011b) ${ }^{5}$ (Grundsatz des Vorrangs des Unionsrechts, principe de primauté du droit de l'UE) belongs to the fundamental principles of EU law. It signifies that in case of a conflict between EU law and the law of the Member States, EU law prevails.

It should thereby be stressed that the principle of primacy does not signify that the CJEU can invalidate the national law,

\footnotetext{
${ }^{2}$ See Article 288 (2) TFEU.

${ }^{3}$ See Article 288 (3) TFEU

${ }^{4}$ See Article 19 (1) TEU.

${ }^{5}$ In the literature, the principle of primacy of EU law is referred to also as the principle of supremacy of EU law.
}

which conflicts with EU law. It rather means that in case of a conflict between national law and directly effective EU law, which cannot be solved by consistent interpretation of national law, national courts of the Member States must apply EU law instead of the national law (see also Lenaerts \& Van Nuffel, 2011). In this context, questions of direct effect of EU law also play an important role, in particular with regard to directives (see e.g. Craig \& De Búrca, 2007; Opinion of Advocate General Trstenjak in Case C-282/10, Dominguez).

The principle of primacy was not written down in the founding Treaties of the EU, but was established by the case-law of the CJEU. Even today, the principle of primacy is not yet embodied in the positive EU-law (meaning that it is not encompassed either in the TFEU or in the TEU) (with regard to the absence of an explicit record of the principle of primacy in TEU or TFEU see Lenaerts \& Van Nuffel, 2011). Nevertheless, it has been valid since 1964. In the planned Treaty establishing a Constitution for Europe, an explicit embodiment of this principle in the positive law was foreseen ${ }^{6}$. However, this Treaty did not enter into force and it was replaced by the Treaty of Lisbon $^{7}$, which does not contain an explicit reference to the principle of primacy. Thus, only a Declaration ${ }^{8}$ concerning primacy annexed to the Treaty of Lisbon and adopted in 2007 by the Intergovernmental conference which adopted the Treaty of Lisbon, refers to the principle of primacy ${ }^{9}$. The Declaration further refers to an Opinion of the Legal Service of the Council on the primacy of EU law from $2007^{10}$.

In accordance with the mentioned Declaration, the EU Treaties and the EU law in general thus take, in accordance with the settled case-law of the CJEU, primacy over the law of the Member States. As mentioned, the Declaration takes further reference to an opinion of the Legal Service of the Council,

\footnotetext{
${ }^{6}$ See Article I-6 of the Treaty establishing a Constitution for Europe, titled "Union law", which provided: "The Constitution and law adopted by the institutions of the Union in exercising competences conferred on it shall have primacy over the law of the Member States."

${ }^{7}$ Treaty of Lisbon amending the Treaty on European Union and the Treaty establishing the European Community, signed at Lisbon, 13 December 2007 OJ 2007 C 306/1. The Treaty of Lisbon amended the Treaty on European Union as well as the Treaty establishing the European Community and renamed the latter Treaty on the Functioning of the European Union. The Treaty of Lisbon thereby replaced the existing European Community and European Union by a new European Union.

${ }^{8}$ Contrary to the protocols to the EU Treaties, the declarations to the Treaties are not binding. However, they can be taken into account by the CJEU when interpreting the corresponding articles of the Treaties; see Lenaerts \& Van Nuffel, 2011.

${ }^{9}$ Declaration concerning primacy is the 17 th declaration, annexed to the Final Act of the Intergovernmental Conference which adopted the Treaty of Lisbon; it is published in the OJ of the EU C 83, 30 March 2010, p. 344. It states: "[T]he Conference recalls that, in accordance with well settled case law of the Court of Justice of the European Union, the Treaties and the law adopted by the Union on the basis of the Treaties have primacy over the law of Member States, under the conditions laid down by the said case law.”

${ }^{10}$ Opinion of the Council Legal Service of 22 June 2007 from the document $11197 / 07$ (JUR 260) states: "It results from the case-law of the Court of Justice that primacy of EC law is a cornerstone principle of Community law. According to the Court, this principle is inherent to the specific nature of the European Community. At the time of the first judgment of this established case law (Costa/ENEL, 15 July 1964, Case 6/64 [*]) there was no mention of primacy in the treaty. It is still the case today. The fact that the principle of primacy will not be included in the future treaty shall not in any way change the existence of the principle and the existing case-law of the Court of Justice.” The following note is added to the reference [*] to the judgment in Costa/ENEL, Case 6/64: "It follows [...] that the law stemming from the treaty, an independent source of law, could not, because of its special and original nature, be overridden by domestic legal provisions, however framed without being deprived of its character as EU law and without the legal basis of the Union itself being called into question.”
} 
which clearly identifies the principle of primacy as a cornerstone principle of the EC law (now EU law) and states that the fact that the principle of primacy would not be included in the Treaty of Lisbon does not change the existence of the principle and the existing case-law of the CJEU.

\section{The Principle of Primacy in the Earlier Case-Law of the CJEU}

The CJEU established the principle of primacy already in 1964 in case 6/64, Costa v ENEL. The case 6/64, Costa v ENEL related to the question of conformity of the Italian law on nationalizing an undertaking for production and distribution of electricity ${ }^{11}$ with provisions of the then Treaty establishing the European Economic Community (hereinafter referred to as: EEC Treaty $)^{12}$. The CJEU explained in the judgment that EU law forms an integral part of the national legal systems, which the national courts are bound to apply. The obligations of the Member States that arise for them from EU law would however be incomplete, if Member States could override them with the national provisions, "however framed"13. Therefore the national legislation cannot prevail over EU law ${ }^{14}$.

The principle of primacy was further shaped by the CJEU in its case-law, which followed some years after the case $6 / 64$, Costa v ENEL. Thus, the CJEU clarified in the case 11/70, Internationale Handelsgesellschaft that the legal nature of the national measure has no relevance to the question of primacy of EU law (see also Craig \& De Búrca, 2007) and that fundamental rights, guaranteed by the constitution or the principles of a national constitutional structure cannot call into question the primacy of EU law ${ }^{15}$. Although the precedence of EU law over any national provision follows already from the judgment in the case 6/64, Costa v. ENEL (see also Grabenwarter, 2010), in the case 11/70, Internationale Handelsgesellschaft the CJEU explicitly confirmed priority of EU law over a provision of a national constitution, including those, which guarantee fundamental rights (Grabenwarter, 2010).

In the case 106/77, Simmenthal, the CJEU stressed that the use of the principle of primacy does not depend on the question whether a national provision was adopted before or after the relevant provision of the EU law, and that in case of a conflict between the national law and the EU law, every national court must give priority to EU law ${ }^{16}$. The national court must refuse to apply the national provision conflicting with EU law, without it being "necessary for the court to request or await the prior setting aside of such provisions by legislative or other constitutional means"17. A national court must thus immediately give effect to EU law (see also Craig \& De Búrca, 2007). Further, the principle of primacy concerns also the national legislator by prohibiting it to adopt new national legislation, which would

\footnotetext{
${ }^{11}$ In concrete, Law No 1643 of 6 December 1962 and the presidential decrees issued in execution of that Law.

${ }^{12}$ The EEC Treaty was amended by the Maastrich Treaty (Treaty on European Union, OJ C 191 of 29 July 1992), which entered into force on 1 November 1993.

${ }^{13}$ Judgement of 15 July 1964 in Case 6/64, Costa v. ENEL [1964] ECR 585, at 594 .

${ }^{14}$ Ibidem.

${ }^{15}$ Judgment of 17 December 1970 in Case 11/70, Internationale Handelsgesellschaft [1970] ECR 1125 (para. 3).

${ }^{16}$ Judgment of 9 March 1978 in Case 106/77, Simmenthal [1978] ECR 629 (para. 21).

${ }^{17}$ Ibidem (operative part).
}

conflict with EU law (see also Craig \& De Búrca, 2007; Avbelj, 2011a) ${ }^{18}$.

With regard to the principle of primacy, two of its further characteristics should thus be set out. On the one hand, the principle of primacy applies regardless of the position of the national provision in the hierarchy of the national law (see Schweitzer, Hummer, \& Obwexer, 2007; Lenaerts \& Van Nuffel, 2011; Craig \& De Búrca, 2007). In practice, this signifies that the EU law prevails even over the national constitutions of the Member States, thus also for example if the national constitution conflicts with an EU directive.

On the other hand, EU law prevails also over the subsequently adopted national law. A Member State can therefore not exclude the application of EU law by subsequent national law, which conflicts with EU law, as the application of lex posterior derogat legi priori in relation between the EU law and the national law would render the achievement of the goals of the Union impossible (Craig \& De Búrca, 2007; Avbelj, 2011a). The fundamental goal of the principle of primacy is thus to assure a unified and effective application of EU law in all Member States.

\section{The Constitutional Courts of the Member States and Their Relationship with EU Law and the CJEU}

\section{Relation of the Constitutional Courts of the Member States to the EU Law and to the CJEU}

The preliminary ruling procedure, regulated in Article 267 TFEU, represents a means of cooperation of the national courts of the Member States with the CJEU (see also Craig \& De Búrca, 2007). In relation to the CJEU, the practice of the constitutional courts of different Member States shows some important differences with regard to making references for a preliminary ruling.

With regard to submitting the references for a preliminary ruling under Article 267 TFEU the Belgian Constitutional Court (Grondwettelijk Hof van België/Cour constitutionnelle de Belgique), which has made already over 10 references ${ }^{19}$, has been the most active. References for a preliminary ruling have been made, among others, also by the Austrian Constitutional Court (Verfassungsgerichtshof Österreich) ${ }^{20}$, the Italian Constitutional Court (Corte costituzionale della Repubblica Italiana $)^{21}$, the Lithuanian Constitutional Court (Lietuvos Respublikos Konstitucinis Teismas) ${ }^{22}$ and the Spanish Constitutional Court (Tribunal Constitucional de España) ${ }^{23}$.

Some constitutional courts seem to reject the possibility to

\footnotetext{
$\overline{{ }^{18} \text { Judgment from } 19 \text { March } 1978 \text { in Case 106/77, Simmenthal [1978] ECR }}$ 629 (para. 17).

${ }^{19}$ Thus e.g. in Case C-93/97, Fédération belge des chambres syndicales de médecins [1998] ECR I-04837; in Case C-305/05, Ordre des barreaux francophones et germanophone and Others [2007] ECR I-05305; in Case C-212/ 06, Government of Communauté française and Gouvernement wallon [2008 ECR I-01683; in Case C-73/08, Bressol and Others [2010] ECR I-02735; in Case C-236/09, Association belge des Consommateurs Test-Achats and Others not yet published in ECR; in Case C-197/11, Libert and Others; or in Case C-375/11 Belgacom and Others.

${ }^{20}$ Case C-143/99, Adria-Wien Pipeline [2001] ECR I-08365; Case C-465/00, Österreichischer Rundfunk and Others [2003] ECR I-04989; and Case C171/01, Wählergruppe' Gemeinsam [2003] ECR I-04301.

${ }^{21}$ Case C-169/08, Presidente del Consiglio dei Ministri [2009] ECR I-10821.

${ }^{22}$ Case C-239/07, Sabatauskas and Others [2008] ECR I-07523.

${ }^{23}$ Case C-399/11, Melloni.
} 
refer questions to the CJEU. In this way, the German Constitutional court (Bundesverfassungsgericht) has not yet made a preliminary ruling reference and has generally a rather unfavourable viewpoint as regards the primacy of EU law over the constitutional norms. The Bundesverfassungsgericht is namely of the opinion that its competence to judge on the conformity of EU legal acts with the German Constitution (Grundgesetz), the s.c. Basic Law (hereinafter referred to as: Grundgesetz) is intact whenever EU law in general does not provide in essence an equal level of protection of fundamental rights as the Grundgesetz.

The legal theory divides Member States into three groups with regard to what their position on the primacy of EU law in relation to the national constitution is: Member States that acknowledge full primacy, Member States that acknowledge limited primacy of EU law in relation to the national constitution, and Member States that principally assume primacy of the national constitution over EU law (for further details, see Grabenwarter, 2010).

\section{Examples of Some Preliminary Ruling References, Related to the Questions of Primacy}

Is a Priority of an Interlocutory Procedure for the Review of Constitutionality in Accordance with EU Law?

Member States prescribe different procedural rules regarding the way in which a preliminary ruling question may be addressed to the CJEU. Below, an example of France will be presented, where a procedure for the review of constitutionality before the French Conseil Constitutionnel is given priority by the legislation over the preliminary ruling procedure at the $\mathrm{CJEU}^{24}$. Due to the question, whether this deprives the courts of exercising their right or fulfilling their obligation under Article $267 \mathrm{TFEU}^{25}$, the question was dealt with also at the CJEU.

The CJEU dealt with this question in joined cases C-188/10 and C-189/10, Melki and Abdeli, on the basis of the references for a preliminary ruling made by the French Cour de Cassation. The main proceedings concerned Mr. Melki and Mr. Abdeli, two Algerian nationals who were unlawfully present in France. After a police control they were each subject of a deportation order and a decision for continued detention. In the procedure, they disputed the lawfulness of the control made on them and alleged that the French Code of Criminal Procedure violates the rights and freedoms guaranteed by the French Constitution,

\footnotetext{
${ }^{24}$ The priority question on constitutionality is defined in Article 61-1 of the French Constitution, and in chapter II bis of Order No 58-1967 of 7 November 1958 on the organic law governing the Conseil constitutionnel (Ordonnance n 58-1967, du 7 novembre 1958, portant loi organique sur le Conseil constitutionnel), as amended by the Organic Law No 2009-1523 of 10 December 2009 (Loi organique n 2009-1523, du 10 décembre 2009). The priority nature is given to it by Order No 58-1967 as amended by the Organic Law No 2009-1523. According to Article 23-2 (2) of Order No 581967 , the court or tribunal must, where pleas are made before it challenging whether a legislative provision is consistent, first, with the rights and freedoms guaranteed by the Constitution, and secondly, with France's international commitments, rule as a matter of priority on whether to submit the question on constitutionality to the Conseil d'Etat or the Cour de cassation. According to Article 23-5 (2) of Order No 58-1967, the Conseil d'Etat or the Cour de cassation however must, where pleas are made before them challenging whether a legislative provision is consistent, first, with the rights and freedoms guaranteed by the Constitution and, secondly, with France's international commitments, rule as a matter of priority on the referral of the question on constitutionality to the Conseil constitutionnel.

${ }^{25}$ See the judgment of 22 June 2010 in Joined Cases C-188/10 and C-189/10, Melki and Abdeli [2010] ECR I-05667 (para. 47).
}

because it is contrary to EU law ${ }^{26}$.

When seized with the question by a lower court whether the national legislation violates the rights and freedoms under the Constitution and EU law, the Cour de cassation considered that in the review of constitutionality procedure the Conseil Constitutionnel would have to rule also on conformity of the Code of Criminal Procedure with EU law and that in case of a positive response, Article 62 of the Constitution ${ }^{27}$ would deny all courts the opportunity to refer a question to the CJEU even after the review of constitutionality procedure ${ }^{28}$. In these circumstances, the Cour de Cassation referred a question to the CJEU whether Article 267 TFEU precludes national legislation, such as that resulting from Order No 58-1067 ${ }^{29}$, which establishes an interlocutory procedure for the review of constitutionality of national laws, requiring the French courts to rule as a matter of priority on whether to refer to Conseil Constitutionnel a question on whether a national law provision is consistent with the Constitution, when at the same time the conflict of that provision with EU law is at issue ${ }^{30}$.

In the grounds of the judgment, the CJEU first referred to its exiting case-law. It stressed that the lower national courts of the Member States retain their right under Article 267 TFEU to refer to the CJEU although a national rule binds them on the points of law by the rulings of a superior court (as ruled e.g. in Case 166/73, Rheinmühlen-Düsseldorf) ${ }^{31}$. It further reminded that a national court is obliged to give full effect to EU law and thus to disapply any conflicting provision of national legislation, without it being necessary for this court to request or await the prior setting aside of such provision by legislative or other constitutional means (as ruled e.g. in Case 106/77, Simmental or Case C-187/00, Kutz-Bauer) ${ }^{32}$. Lastly, it explained that according to the existing case-law of the CJEU, an obligatory referral of a matter to a constitutional court of a Member State does not deprive the national court of its right or obligation under Article 267 TFEU to refer to the CJEU questions concerning the interpretation or validity of EU law (as ruled in Case C-348/89, Mecanarte) ${ }^{33}$.

The CJEU concluded that the functioning of the system of cooperation under Article 267 requires the national court to be free to refer to the CJEU for a preliminary ruling. However, a national law preventing the national court from immediately disapplying a national provision which it considers to be contrary to EU law, is acceptable, if the national court remains free to adopt measures of provisional judicial protection of the rights conferred under EU law and "to disapply, at the end of [...] an interlocutory procedure, that national legislative provision if that court holds it to be contrary to EU law."34

\footnotetext{
${ }^{26}$ Summarized from ibidem (para. 16, 17 and 19).

${ }^{27}$ Article 62 of the French Constitution determines that decisions of the Conseil constitutionnel are binding on public and administrative authorities and courts.

${ }^{28}$ Summarized from the judgment of 22 June 2010 in Joined Cases C-188/10 and C-189/10, Melki and Abdeli [2010] ECR I-05667 (para. 21 and 46). It should be stressed that Conseil Constitutionnel and Conseil d'Etat held such interpretation of the priority question on constitutionality procedure to be wrong, these decisions being relied upon by the French government-see judgment of 22 June in Joined Cases C-188/10 and C-189/10, Melki and Abdeli [2010] ECR I-05667 (para. 33-36).

${ }^{29}$ See above Fn. 20.

${ }^{30}$ Judgment of 22 June 2010 in Joined Cases C-188/10 and C-189/10, Melki and Abdeli [2010] ECR I-05667 (para. 31).

${ }^{31}$ Ibidem (para. 42).

${ }^{32}$ Ibidem (para. 43).

${ }^{33}$ Ibidem (para. 45)

${ }^{34}$ Ibidem (para. 52 in 53).
} 
Based on the above observations, the CJEU decided that Article 267 TFEU precludes a national legislation establishing a priority interlocutory procedure for the review of constitutionality, if it prevents the national courts of a Member State to refer questions to the CJEU for a preliminary ruling both before the submission of a question on constitutionality and after the decision of constitutional court on that question. However, a national legislation establishing a priority interlocutory procedure for the review of constitutionality is acceptable, if other national courts 1 ) remain free to refer to make a preliminary ruling reference at whatever stage of the proceedings they consider appropriate (even at the end of the interlocutory procedure for the review of constitutionality); 2) to adopt measures of provisional judicial protection; and 3) to disapply, at the end of such an interlocutory procedure, the national legislative provision at issue, contrary to EU law ${ }^{35}$.

The judgment of the CJEU has brought up numerous responses, particularly in France (see e.g. Marti, 2010; Sarmiento, 2010; Simon \& Rigaux, 2010). The judgment is important especially because the CJEU further developed its case-law on the relationship between the constitutional courts of the Member States and the CJEU (see also Sarmiento, 2010). The CJEU did not find the interlocutory procedure for the review of constitutionality to be contrary to Article 267 TFEU in any event, but has linked its conformity to fulfilment of the above-mentioned conditions. The theory stresses that in contrast to the previous case-law, this judgment thus allowed interferences in the procedure of making a preliminary ruling reference to the CJEU (Sarmiento, 2010).

\section{Unconstitutionality of a Law of a Member State, Established by a Decision of the National Constitutional Court in Relation to EU Law}

Questions on the relationship between EU law and the national law also arise in situations, where a constitutional court of a Member State has already judged on the constitutionality of a certain law, which might also be contrary to EU law. In this way, in a case discussed below, the Polish Constitutional court (Trybunat Konstytucyjny) ruled the provisions of the national law to be incompatible with the Constitution, but deferred the date on which these provisions would lose their binding force. In these circumstances, the national court was faced with the question whether the principle of primacy obliges it to apply EU law (and not the provisions of national law) before the judgment of the Trybunat Konstytucyjny on the unconstitutionality of the national provisions comes into effect, if these national provisions are incompatible with EU law ${ }^{36}$.

The CJEU dealt with this question in C-314/08, Filipiak, where the preliminary ruling reference was made by the Regional Administrative Court in Poznan, Poland (Wojewódzki Sad Administracyjny w Poznaniu). The main proceedings related to the Polish legislation, which did not allow for social security contributions to be deducted from the basis of tax assessment and for income tax to be reduced by the amount of the health insurance contributions, if these contributions were paid in another Member State, although they were not deducted in the other Member State ${ }^{37}$. Although the Trybunat Konstytucyjny held the national provisions at issue to be not compatible

\footnotetext{
${ }^{35}$ Ibidem (point 1of the operative part).

${ }^{36}$ Summarized from the judgment of 19 November 2009 in Case C-314/08, Filipiak [2009] ECR I-11049 (para. 44).

${ }^{37}$ Summarized from Ibidem (para. 22 and 74).
}

with the principle of equality and the principle of social justice, set out in the Constitution, it decided to defer the date on which the provisions held to be unconstitutional would lose all binding force. The Wojewódzki Sad Administracyjny w Poznaniu, which dealt with the case, considered it to still be necessary to examine whether the provisions at issue are compatible with Article 43 of the EC Treaty ${ }^{38}$ (now Article 49 TFEU) and referred a question relating to the interpretation of Article 49 TFEU to the CJEU ${ }^{39}$. In view of the judgment of the Trybunat Konstytucyjny it referred also a question, asking whether the principle of the primacy of EU law following from Article 4(3) TEU $^{40}$ and Article 49(1) and 49(2) TFEU ${ }^{41}$ must be construed as taking precedence over the provisions of national Constitution, on the basis of which the entry into force of a judgment of the Trybunat Konstytucyjny was deferred ${ }^{42}$.

With regard to the latter question, the CJEU explained in its judgement that primacy of EU law requires a national court of a Member State to refuse, if necessary, to apply a national provision, conflicting with a directly applicable provision of the Treaty. A conflict between a national provision and EU law however does not require a declaration that the national provision is invalid, nor does it render a national provision non-existent $^{43}$. It is thus not surprisingly that the CJEU ruled that in circumstances where EU law precludes national legislation, "the primacy of [EU] law obliges the national court to apply [EU] law and to refuse to apply conflicting provisions of national law, irrespective of the judgment of the national constitutional court which has deferred the date on which those provisions, held to be unconstitutional, are to lose their binding force." 44

\section{The National Constitution of Member States in Relation to the EU Directives and Primacy of EU Law}

As it has already been mentioned, the principle of primacy of EU law applies regardless of where in the hierarchy of the national law a national legal act is positioned. Thus, EU law takes primacy also over the national constitution of a Member State, including for example if the national constitution is in conflict with an EU directive.

In this connection, the case C-285/98, Tanja Kreil should be mentioned, as it has led even to an amendment of the German Grundgesetz. The case results from a dispute that arose when Ms. Kreil applied for a voluntary service in the Federal Armed Forces (Bundeswehr), involving the use of arms. After her application was rejected, she brought an action at the Administrative Court in Hannover (Verwaltungsgericht Hannover). She claimed that the rejection of her application, which was based only on her sex, was contrary to EU law. Verwaltungsgericht Hannover therefore referred a question to the CJEU for a preliminary ruling, asking whether the German national legislation infringes the Directive 76/207 on the implementation of the principle of equal treatment for men and women as regards access to employment, vocational training and promotion, and

\footnotetext{
${ }^{38}$ EC Treaty was amended by the Treaty of Lisbon (see FN 11), which entered into force on 1 December 2009.

${ }^{39}$ Summarized from Ibidem (para. 22).

${ }^{40}$ Before Article 10 EC Treaty.

${ }^{41}$ Before Article 43(1) in (2) EC Treaty.

${ }^{42}$ Judgement of 19 November 2009 in Case C-314/08, Filipiak [2009] ECR

I-11049 (para. 26).

${ }^{43}$ Ibidem (para. 82-84).

${ }^{44}$ Ibidem (point 2 of the operative part).
} 


\section{TRSTENJAK}

working conditions ${ }^{45}$ (hereinafter referred to as: Directive 76/ 207) by providing that women who enlist as volunteers may be engaged in the Bundeswehr only in the medical and militarymusic services and are excluded in any event from armed service. The German Law on Soldiers (Soldatengesetz) and the Regulations on Soldiers' Careers (Soldatenlaufbahnverordnung) had their basis in Article 12a of the Grundgesetz (for further details, see Starck, 2005) ${ }^{46}$, i.e. the German Constitution, which provided that men may be required to serve in the armed forces $^{47}$ and that women may on no account render service involving the use of arms ${ }^{48}$.

The CJEU decided that the Directive 76/207 "precludes the application $^{49}$ of national provisions, such as those of German law, ${ }^{50}$ which impose a general exclusion of women from military posts involving the use of arms and which allows them access only to the medical and military-music services."51

Since the national legislation at issue was supported by a provision of the Grundgesetz, the judgment of the CJEU in this case confirmed the primacy of EU law over constitutional law as well. The judgment was subject to several responses in the literature (see e.g. Lenz, 2000; Köster \& Schröder, 2000; Görlitz, 2002; Scholtz, 2000) and has also lead to an amendment of the Grundgesetz ${ }^{52}$. The latter now provides in Article 12a (4) that women should on no account be obliged to render service involving the use of arms.

\section{Conclusion}

The principle of primacy remains one of the central pillars for ensuring a uniform interpretation and application of EU law in all Member States. In this regard, the crucial role of the national courts of the Member States, including the constitutional courts, which they can play through a dialogue with the CJEU and their application of EU law, should not be neglected. Within the context of the European hierarchy, the constitutional courts of the Member States are left with the central role and power of review of constitutionality, but it remains to be seen whether in future more constitutional courts will enter a dialogue with the CJEU in the form of a preliminary ruling procedure.

Today, EU law is becoming one of the most connecting factors in the EU. However, in order for the law to be really effective and to ensure justice, courts are needed as well. For we no longer live in the Golden Age, described in Ovid's Metamorphoses, where justice existed without the laws and without the courts. Today, we need the laws as well as the courts, and in a built up legal system, only a synergy between the national

\footnotetext{
$\overline{{ }^{45} \text { Council Directive 76/207/EEC of } 9 \text { February } 1976 \text { on the implementation }}$ of the principle of equal treatment for men and women as regards access to employment, vocational training and promotion, and working conditions (OJ 1976 L 39, p. 40).

${ }^{46}$ In Germany, the highest constitutional act is named Grundgesetz (Basic Law) and not Verfassung (Constitution), which has historical reasons.

${ }^{47}$ Article 12a (1) of the Grundgesetz.

${ }^{48}$ Article 12a (4) last sentence, of the Grundgesetz, in text, valid in the time of dispute, provided: "[Frauen] dürfen auf keinen Fall Dienst mit der Waffe leisten."

${ }^{49}$ Stressed by the author.

${ }^{50}$ Stressed by the author.

${ }^{51}$ Judgment of 11 January 2000 in Case C-285/98, Tanja Kreil [2000] ECR I-00069 (operative part).

${ }^{52}$ Article 12a (4) last sentence of the Grundgesetz now provides: “[Die Frauen] dürfen auf keinen Fall zum Dienst mit der Waffe verpflichtet werden.”
}

courts and the CJEU can lead to justice, legality and efficiency of law.

\section{REFERENCES}

Avbelj, M. (2011a). Sodno pravo evropske unije. Ljubljana: GV Založba.

Avbelj, M. (2011b). Supremacy or primacy of EU law-(Why) does it matter? European Law Journal, 17, 744-763. doi:10.1111/j.1468-0386.2011.00560.x

Basedow, J. (2010a). Der europäische gerichtshof und das privatrecht. Über unsicherheiten, allgemeine Grundsätze und die europäische justizarchitektur. Archiv für die civilistische praxis, 157.

Basedow, J. (2010b). The court of justice and private law: Vacillations, general principles and the architecture of the European judiciary. European Review of Private Law, 443.

Craig, P., \& De Búrca, G. (2007). EU law, text, cases and materials (4th ed.). Oxford: Oxford University Press.

Danwitz von, T. (2010). Die aufgabe des gerichtshofes bei der entfaltung des europäischen Zivil- und Zivilverfahrensrechts. Zeitschrift für Europäisches Privatrecht, 463.

Görlitz, N. (2002). Die beschränkung der wehrpflicht auf männer und europarechtliche diskriminierungsverbote. Die Öffentliche Verwaltung, 55, 607-613.

Grabenwarter, C. (2010). National constitutional law relating to the European Union. In: A. Bogdandy von and J. Bast (Eds.), Principles of european constitutional law (2nd ed.). Oxford: Hart Publishing.

Köster, C., \& Schröder, J. (2000). Nachhilfe vom EuGH: Frauen an die Waffe! Juristische Schulung, 6, 542-546.

Lenaerts, K., \& Van Nuffel, P. (2005). Constitutional law of the European Union (2nd ed.). London: Sweet \& Maxwell.

Lenaerts, K., \& Van Nuffel, P. (2011). European union law (3th ed.). London: Thomson Reuters, Sweet \& Maxwell.

Lenz, C. O. (2000). Frauen im dienst mit der waffe-Nationales reservat oder europäische gleichberechtigung? Zum urteil kreil gegen bundesrepublik deutschland. Zeitschrift für Rechtspolitik, 7, 265-268.

Marti, G. (2010). L'arrêt melki de la cour de justice: La clef d'un pluralisme constitutionnel renforcé? Revue des Affaires Européennes-Law \& European Affairs, 17, 889-904.

Sarmiento, D. (2010). L'arrêt melki: Esquisse d'un dialogue des juges constitutionnels Européens sur toile de fond française. Revue Trimestrielle de Droit Européen, 3, 588-598.

Scholtz, R. (2000). Frauen an die waffe kraft Europarechts? Die Öffentliche Verwaltung, 53, 417-421.

Schweitzer, M., Hummer, W.. \& Obwexer, W. (2007). Europarecht, das recht der Europäischen union. Vienna: Manz.

Simon, D., \& Rigaux, A. (2010). La priorité de la question prioritaire de constitutionnalité: Harmonie(s) et dissonance(s) des monologues juridictionnels croisés. Les Nouveaux Cahiers du Conseil Constitutionnel, 29, 63-83. doi:10.3917/nccc.029.0063

Starck, C. (2005). Verkündungsformel und präambel. In: H. Mangoldt, F. Klein and C. Starck, Kommentar zum grundgesetz. Band 1. München: Vahlen. 